\title{
DA (IN) EFETIVIDADE DOS DIREITOS HUMANOS À DENEGAÇÃO DE DIREITOS POLÍTICOS: REFLEXÕES CONSTITUCIONAIS
}

\author{
Bruna Mariana Blos Hepp* \\ Janaína Machado Sturza**
}

\section{RESUMO}

Os desafios da democracia, no sentido de promover e efetivar uma cidadania capaz de consagrar os direitos humanos no Estado democrático atual é tema de inúmeras interlocuções. A Constituição Federal Brasileira traz o voto como uma das formas mais importantes de exercício da cidadania. Seguindo este ideário, através de uma abordagem doutrinária que segue o método hipotético dedutivo, o texto tem como objetivo fomentar a reflexão acerca da atual conjuntura constitucional, pontualmente sobre a denegação do direito político ao voto do preso provisório. Verifica-se que tal situação representa a privação do exercício de um direito fundamental - $o$ direito ao voto.

Palavras-chave: Direitos Humanos. Direito de Sufrágio. Direitos Políticos. Voto do Preso Provisório. Democracia.

\section{FROM THE (IN) EFFECTIVENESS OF HUMAN RIGHTS TO THE DENIAL OF POLITICAL RIGHTS: CONSTITUTIONAL REFLECTIONS}

\begin{abstract}
The challenges of democracy, in the sense of promoting and realizing a citizenship capable of consecrating human rights in the current democratic state, are subject to numerous dialogues. The Brazilian Federal Constitution brings voting one of the most important forms of exercising

\footnotetext{
* Graduada em Direito pela Universidade do Vale do Rio dos Sinos - UNISINOS (2011). Mestranda em Direito pelo Programa de Pós-Graduação Stricto Sensu, com área de concentração em Direitos Humanos no Centro Universitário Ritter dos Reis - Rede Laureate International Universities (UniRitter). Atualmente desenvolve pesquisas na área de Direito Eleitoral, Direito Constitucional e Teoria dos Sistemas. Advogada.

${ }_{* *}^{*}$ Pós doutora em Direito pelo Programa de Pós Graduação em Direito da Universidade do Vale do Rio dos Sinos - UNISINOS. Doutora em Direito pela Escola Internacional de Doutorado em Direito e Economia Tullio Ascarelli, da Universidade de Roma Tre/Itália. Mestre em Direito pela Universidade de Santa Cruz do Sul - UNISC. Especialista em Demandas Sociais e Políticas Públicas também pela UNISC. Graduada em Direito pela UNISC. Professora no PPG em Direitos Humanos - Mestrado, da Unijui.
} 
citizenship. According to this ideology, through a doctrinaire approach following the hypothetical deductive method, our text aims to foster reflection in the current constitutional conjuncture, specifically in the denial of the political right to vote of the provisional prisoner. Moreover, such a situation amounts to a deprivation of the fundamental right - to vote.

Keywords: Human Rights. Right of Suffrage. Political Rights. Provisional Prison Vote. Democracy.

\section{Considerações iniciais}

O berço da democracia abraça como princípios democráticos a igualdade e a liberdade, que a início parece andarem sempre juntos, mas, no entanto, são diferentes e às vezes opostos, principalmente no que tange aos seus efeitos. Por exemplo, todos tem igual direito de votar, mas nem todos tem a liberdade de exercer tal direito, como é o caso daqueles que estão presos provisoriamente. Este artigo se propõe a desenvolver acerca da denegação de direitos políticos aos presos provisórios que é constitucionalmente reconhecido, pois estão em pleno gozo por ainda não possuírem condenação transitada em julgado, mas precariamente implementado.

Assim, o presente artigo traz a discussão acerca da garantia dos direitos humanos, do respeito do direito de exercício da cidadania por parte dos presos provisórios através do sufrágio universal. Os objetivos específicos são: a) mostrar a importância do sufrágio universal e dos direitos políticos; b) o reconhecimento do exercício do voto dos presos provisórios; c) a omissão da Justiça Eleitoral Brasileira em adotar medidas necessárias a viabilização do direito; d) relatar como alguns países da América do Sul e Europa tratam a presente questão; e d) relacionar o caso com a aplicação dos direitos humanos.

Ao tratar o direito de voto do preso provisório como um mero privilégio, comprometese seriamente a integridade do princípio democrático que pressupõe a inclusão política do povo, ferindo o direito subjetivo, líquido e certo dos presos provisórios de votarem. Tal exclusão expõe todo o preconceito que existe contra os presos na sociedade que, além de estarem privados de liberdade, também acabam por ser privados de seus direitos políticos em razão da omissão da Justiça Eleitoral Brasileira em adotar medidas necessárias à sua viabilização.

Assim, a pesquisa mostra a importância do sufrágio universal, o conceito dos direitos políticos e do preso provisório, o exercício do voto do preso provisório no Brasil e em alguns países da América do Sul e Europa. 


\section{A importância do sufrágio universal}

A Carta Magna nos traz, em seu artigo 14, caput, que a soberania popular será exercida pelo sufrágio universal e pelo voto direto e secreto, com valor igual para todos (BRASIL, 2010, p. 24).

Sufrágio, na lição do mestre José Afonso da Silva (2002, p. 110), é um direito público subjetivo de natureza política que tem o cidadão de eleger, ser eleito e de participar da organização e da atividade do poder estatal.

Como direito político, o sufrágio acaba por ser vinculado aos fatores condicionantes da organização estatal e jurídica. Nessa linha, Miguel Reale (2000, p. 96) entende que o Direito é síntese ou integração de ser e de dever ser, é fato e é norma, pois é o fato integrado na norma exigida pelo valor a realizar.

O sufrágio é um instrumento fundamental de realização do princípio democrático, sendo que é através dele que se legitima democraticamente a conversão da vontade política em posição de poder e domínio, se estabelece a organização de distribuição de poderes, se procede à criação de "pessoal político" e marca-se o ritmo da vida política de um país. Destacado, então, toda a importância do sufrágio no regime democrático.

O sufrágio universal é aquele que exprime sufrágio de todos, sem restrições ou sem limitações; é a qualidade de eleitor posta ao alcance de todo cidadão e requer preceitos legais para determinar as regras de sua viabilização.

Tais regras variam entre conteúdo e eficácia, mas sempre em consonância com a realidade cultural da sociedade a que se aplicam. Isto resulta na impossibilidade de existência de um só tipo de sistema eleitoral, o qual se pode definir como "o conjunto de normas, instituições e práticas que configuram os processos eleitorais de uma sociedade dada" (CARRERAS; VALLES, 1977, p. 236).

O direito de sufrágio abrange dois aspectos: o direito de votar, chamada de capacidade eleitoral ativa e o direito de ser votado, chamado de capacidade eleitoral passiva.

No ensinamento de Maria Arair Pinto Paiva (1985, p. 112) o sufrágio ativo é o direito de participação do cidadão no processo político do Estado, exercitado através do voto, enquanto que o sufrágio passivo é o direito de ser votado, de ser candidato e preencher os cargos constantes da estrutura político-jurídica do país. 
No sufrágio universal não se faz qualquer restrição ao cidadão, em razão de fortuna, ou de instrução e no sufrágio direto se estabelece em um só grau, isto é, aquele em que as pessoas autorizadas a votar já escolhem os nomes de seus candidatos, com a indicação dos cargos correspondentes (SILVA, 2001, p. 265).

Numa particular e restrita postura, sufrágio universal significa que todos tem o direito de votar, indistintamente e indiscriminadamente; pois a disposição dos direitos políticos, mesmo que em parte, é a única forma que o povo tem de interferir nas ações governamentais dos que o representam.

Dentro de um regime democrático, para que o cidadão possa participar na escolha de seus representantes, o direito de sufrágio é indispensável e essencial para expressar a vontade do povo, a soberania popular. O sufrágio é exercido pelo voto, que tem, também, natureza sociopolítica e deve ter valor igual para todos, além de ser um direito público subjetivo democrático e representa, nas palavras de Maurice Hauriou (2003, p. 543), "operação de assentimento e ato de confiança”.

Assim, o sufrágio exprime o assentimento com uma candidatura ou proposta e a adesão - sentimento de confiança - a ela (KIMURA, 2006, p. 243).

Muito embora sufrágio não seja sinônimo de voto, um não existe sem o outro, pois o voto é o instrumento, é a ferramenta de exercício do direito de sufrágio.

Explica Silva (2000, p. 352):

[...] as palavras sufrágio e voto são empregadas comumente como sinônimos. A Constituição, no entanto, dá-lhes sentidos diferentes, especialmente, no seu artigo 14, por onde se vê que o sufrágio é universal e o voto é direto e secreto e tem igual valor. A palavra voto é empregada em outros dispositivos, exprimindo a vontade num processo decisório. Escrutínio é outro termo com que se confundem as palavras sufrágio e voto. É que os três se inserem no processo de participação do povo no governo, expressando: um, o direito (sufrágio); outro, o seu exercício (o voto) e o outro, o modo de exercício (escrutínio).

No domínio do Direito Constitucional, o voto representa a opinião de cada indivíduo, a quem se comete a faculdade e o dever de votar (SILVA, 2001, p. 302).

Nos termos de Alexandre de Moraes (2003, p. 219), o voto é um direito subjetivo, sem contudo deixar de ser uma função política e social de soberania popular na democracia representativa.

O autor supracitado assegura ainda as características do voto: personalidade (só pode ser exercido pessoalmente), obrigatoriedade de comparecimento (para os que forem 
enquadrados na obrigatoriedade de votar), liberdade (de escolha, podendo o eleitor votar em branco ou até mesmo anular o voto), sigilosidade, direto, periodicidade (mandados com prazo determinado), igualdade (todos os votos possuem igual valor).

Pelo voto, além da escolha de governantes e de representantes, busca-se, também, segundo Pedro Henrique Távora Niess (2000, p. 84), "o referendo da população sobre a conveniência de uma lei feita (referendum deliberativo) ou por fazer (referendum consultivo), este também nominado plebiscito."

$\mathrm{O}$ voto é necessário para que se exerça o direito de escolha. Ele pode ser secreto ou público, direto ou indireto, obrigatório ou facultativo, igual ou desigual. A Carta Magna Brasileira, em seu artigo 14, consagrou o voto como secreto, obrigatório para os cidadãos entre 18 e 70 anos, facultativo para os analfabetos e para os eleitores de 16 a 18 anos e os maiores de 70 anos, direto, com a exceção prevista no artigo $81, \S 1^{\circ}$, na hipótese de vacância simultânea dos cargos de Presidente e Vice-Presidente da República, nos últimos dois anos do mandato, sendo que possui igual valor para todos os cidadãos.

O voto ainda está na Declaração Universal dos Direitos Humanos de $1948^{1}$, em seu artigo 21, 1: "Toda pessoa tem direito de participar no governo de seu país, diretamente ou por meio de representante livremente escolhido."

\section{Dos direitos políticos no contexto constitucional atual}

A Constituição Federal trata dos direitos políticos no Capítulo IV, artigos 14 a 16, oferecendo os princípios básicos desses direitos, no sentido estrito, cujas minudências ficam a cargo do Código Eleitoral e das demais normas infraconstitucionais.

Com o advento da democracia, um número maior de pessoas passou a interferir na vida política através do uso e gozo dos direitos políticos.

Moraes (2003, p. 232) conceitua direitos políticos como "direitos públicos subjetivos que investem o indivíduo no "status activae civitatis", permitindo-lhe o exercício concreto da liberdade de participação nos negócios políticos do Estado, de maneira a conferir os atributos da cidadania”.

\footnotetext{
${ }^{1}$ Disponível em: 〈http://portal.mj.gov.br/sedh/ ct/legis_intern/ddh_bib_inter_universal.htm〉, acesso em 22 abr. 2017.
} 
Para que possamos exercer nossos direitos políticos, temos que ser cidadãos, o que significa, em nosso ordenamento, adquirir a cidadania, que nada mais é do que o indivíduo ter, para si, o atributo político necessário para participar no governo, podendo exercer os direitos de votar e de ser votado.

No pensamento de Silva (2000, p. 350):

[...] a cidadania se adquire com a obtenção da qualidade de eleitor, que documentalmente se manifesta na posse do título de eleitor válido. O eleitor é cidadão, é titular de cidadania, embora nem sempre possa exercer todos os direitos políticos. É que o gozo integral destes dependem do preenchimento de condições que só gradativamente se incorporam no cidadão [...] é atributo jurídico-político que o nacional obtém desde o momento em que se torna eleitor [...].

Os direitos políticos são abrangidos como direitos de participação do povo no poder do Estado, envolvendo os regimes políticos, os partidos políticos e as formas de participação popular no Poder do Estado (COÊLHO, 2008, p. 252).

José Afonso (2002, p. 231) classifica os direitos políticos como ativos e passivos, ligados respectivamente à capacidade eleitoral ativa - capacidade de votar - e à capacidade eleitoral passiva - capacidade de ser votado. O autor também separa os direitos políticos como positivos e negativos. Os positivos incidem no campo de normas que asseguram o direito subjetivo de participação no processo político e nos órgãos governamentais, garantindo a participação do povo no poder de determinação política. Já os negativos, versam sobre as regras que privam o cidadão, pela perda definitiva ou temporária, da totalidade dos direitos políticos de votar e ser votado, bem como daquelas regras que determinam restrições à elegibilidade do cidadão.

Os direitos políticos se constituem num bloco de direitos diferente dos direitos e garantias individuais e dos direitos sociais, que protegem e beneficiam os indivíduos, conforme leciona o Ilustre Ministro Ayres Britto (TSE, RO 1069, 20.09.2006).

Kimura (2006, p. 293) assevera que os direitos políticos defluem como condição necessária à democracia, pois se exige representação e instrumentos diretos de participação popular como fundamentais à participação do povo na formação da vontade do Estado.

Sampaio Dória (1960, p. 324) afirma que "são políticos os direitos de participar na constituição e no exercício do poder. São, pelo menos dois, irredutíveis: o de votar e o de ser votado; o sufrágio e a elegibilidade." 
No ensinamento de José Afonso da Silva (2002, p. 295), o direito democrático de participação do povo no governo, ao eleger representantes, acaba exigindo a formação de um conjunto de normas legais permanentes, que o autor denomina de direitos políticos.

Pimenta Bueno, citado por Alexandre de Moraes (2004, p. 220), apresenta a definição clássica de direitos políticos, stricto sensu:

[...] as prerrogativas, os atributos, faculdades ou poder de intervenção dos cidadãos ativos no governo de seu país, intervenção direta ou só indireta, mais ou menos ampla, segundo a intensidade do gozo desses direitos. São os jus civitatis, os direitos cívicos que se referem ao Poder Público, que autorizam o cidadão ativo a participar na formação ou exercício da autoridade nacional, a exercer o direito de vontade ou eleitor, o direito de deputado ou senador, a ocupar cargos políticos e a manifestar suas opiniões sobre o governo do Estado.

Os direitos políticos são direitos fundamentais, assim classificados pela Constituição Federal e se inserem na concepção dos direitos fundamentais de primeira geração. Essa é a lição de Paulo Bonavides (2002, p. 517):

Os direitos da primeira geração são os direitos da liberdade, os primeiros a constarem do instrumento normativo constitucional, a saber, os direitos civis e políticos, que em grande parte correspondem, por um prisma histórico, àquela fase inaugural do constitucionalismo do Ocidente.

Como estão os direitos políticos ligados ao princípio da liberdade, que guia os direitos fundamentais de primeira geração, tem-se que o seu exercício confere a todo cidadão, sem distinção e com valor igual para todos, liberdades políticas e, assim, direito de participar, intervir, direta ou indiretamente, na organização e funcionamento do Estado. Tais direitos consubstanciam-se em princípio universal consagrado no artigo 21, 1 e 3, da Declaração Universal dos Direitos Humanos de 1948²:

1. Toda pessoa tem o direito de tomar parte no governo de seu país diretamente ou por intermédio de representantes livremente escolhidos.

$[\ldots]$

3. A vontade do povo será a base da autoridade do governo; esta vontade será expressa em eleições periódicas e legítimas, por sufrágio universal, por voto secreto ou processo equivalente que assegure a liberdade de voto.

\footnotetext{
${ }^{2}$ Disponível em: <http://portal.mj.gov.br/sedh/ ct/legis_intern/ddh_bib_inter_universal.htm>, acesso em 22 abr. 2017.
} 
A decorrência desse direito de participação, segundo José Afonso da Silva (2002, p. 344-345), é o atributo político denominado cidadania, exercido pelo titular de direitos políticos:

\begin{abstract}
Cidadania qualifica os participantes da vida do Estado, é atributo das pessoas integradas na sociedade estatal, atributo político decorrente do direito de participar no governo e direito de ser ouvido pela representação política. Cidadão, no direito brasileiro, é o indivíduo que seja titular dos direitos políticos de votar e ser votado e suas consequências.
\end{abstract}

A conquista da qualidade de cidadão envolve direitos políticos, civis e sociais e irradia deveres perante o Estado. Contudo, não se restringe, exclusivamente, às relações jurídicas de direitos e deveres do indivíduo perante o Estado, mas também perante a comunidade em que se insere. O titular de direitos políticos, nesta qualidade, é também titular da soberania, que será exercida, na forma prescrita no artigo 14 da Constituição Federal (BRASIL, 2010, p. 24):

Art. 14. A soberania popular será exercida pelo sufrágio universal e pelo voto direto e secreto, com valor igual para todos, e, nos termos da lei, mediante:

I - plebiscito;

II - referendo:

III - iniciativa popular.

Cândido destaca ainda que sem os direitos políticos, o indivíduo "morre" para a vida pública. Não poderá participar de nada para o qual se exija o gozo dos direitos políticos (CÂNDIDO, 2003, p. 262).

\title{
2.1 Da Perda dos Direitos Políticos
}

Passam a ser chamados de direitos políticos negativos, os direitos políticos que acabam por ser suspensos ou cassados, de forma definitiva ou permanente.

José Afonso da Silva (2002, p. 362) ressalta que as determinações constitucionais que importem em privar o cidadão do direito de participação no processo político e nos órgãos governamentais são os direitos políticos negativos. Negam, portanto, ao cidadão o direito de votar e ser votado, de organizar e participar de partidos políticos e de exercer função pública.

A nossa Carta Magna prevê no seu artigo 15 (BRASIL, 2010, p. 24), em duas hipóteses, incisos I e IV, a perda dos direitos políticos: o cancelamento da naturalização por 
sentença transitada em julgado e a recusa de cumprir obrigação a todos imposta ou prestação alternativa.

Kimura (2006, p. 314) ressalta que o cancelamento da naturalização, por sentença transitada em julgado, ocorrerá quando o naturalizado exercer atividade nociva ao interesse nacional (art. 12, § 4 ${ }^{\circ}$, I da Constituição Federal de 1988) ${ }^{3}$ e que esta situação deflagra a perda da nacionalidade brasileira, requisito fundamental para o exercício dos direitos políticos.

Pedro Henrique Távora Niess (2000, p. 38) observa que "como se trata de cancelamento dos direitos políticos, a sentença que o determinar produzirá efeitos 'ex nunc', isto é, desde quando passar em julgado, pois o título de eleitor foi validamente concedido".

A segunda hipótese prevista pela Constituição da República acerca da perda dos direitos políticos, trata da recusa ao cumprimento de determinada obrigação por escusa de consciência, manifestando-se ainda a possibilidade de prestação alternativa. Descumprida a obrigação e, logo após, a prestação alternativa, haverá a perda dos direitos políticos, pois inexiste termo final pré-demarcado pelo qual serão readquiridos os direitos políticos.

A Lei Federal no 8.239, de 04.10.1991, que regulamentou os $\S \S 1^{\circ}$ e $2^{\circ}$ do artigo 143 da $\mathrm{CF} / 88$, diz expressamente em seu artigo $4^{\circ}, \S 2^{\circ}$ que ultrapassado o prazo de dois anos para prestação do serviço alternativo, "será emitido após a decretação, pela autoridade competente, da suspensão dos direitos políticos do inadimplente, que poderá, a qualquer tempo, regularizar sua situação mediante cumprimento das obrigações devidas." (BRASIL. Lei $N^{o}$ 8.239, de 4 de Outubro de 1991. Disponível em: <https://www.planalto.gov.br/ccivil_03/leis/18239.htm>, acesso em 15 abr. 2017).

\subsection{Da Suspensão dos Direitos Políticos}

A suspensão dos direitos políticos consiste na privação temporária dos direitos políticos. A Constituição Federal Brasileira traz três hipóteses importantes da suspensão dos direitos políticos, quais sejam:

Art. 15. É vedada a cassação de direitos políticos, cuja perda ou suspensão só se dará nos casos de:

\footnotetext{
${ }^{3}$ Art. $12, \S 4^{\circ}$, I da Constituição Federal Brasileira - Será declarada a perda da nacionalidade do brasileiro que: I) tiver cancelada sua naturalização, por sentença judicial, em virtude de atividade nociva ao interesse nacional. BRASIL. Vade Mecum RT. 5 ed. re. ampl. e atual. São Paulo: Editora Revista dos Tribunais, 2010.
} 


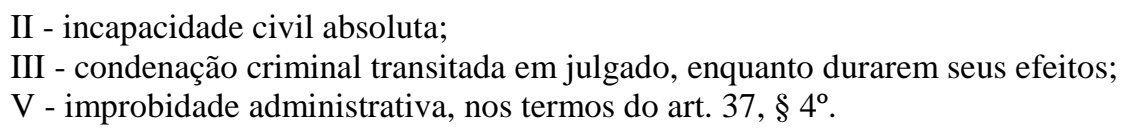

Para se ter a capacidade política, é imprescindível que se tenha a capacidade civil, consoante o inciso II do artigo supracitado. Assim, a perda da capacidade civil faz com que os direitos políticos fiquem suspensos até que haja a recuperação desta.

O inciso III é o que norteia o presente artigo. Isso porque, o principal objetivo deste é atestar que não há limitação alguma ao exercício do direito de voto àqueles que estão presos de forma provisória, sem ter uma condenação transitada em julgado.

Já o inciso $\mathrm{V}$, trata acerca dos direitos políticos daqueles que possuem ação de improbidade administrativa que priva seu direito ao sufrágio.

No dizer expressivo de Rodrigo López Zílio (2008, p. 176), desimporta para a aplicação da norma constitucional mencionada, a espécie de pena aplicada ao réu. Assim, tanto a condenação por pena privativa de liberdade (seja a pena de reclusão, detenção ou prisão simples), como a pena restritiva de direitos (prestação de serviços à comunidade, prestação pecuniária, interdição temporária de direitos, limitação de fim de semana) ou a pena de multa implica a suspensão de direitos políticos.

É unânime a doutrina quanto ao fato de o tempo da suspensão dos direitos políticos ter por termo final a extinção da pena e das medidas de segurança ou o cumprimento da pena. Tanto é assim que o Tribunal Superior Eleitoral já sumulou a questão: "Súmula $n^{o}$ 9. A suspensão de direitos políticos decorrente de condenação criminal transitada em julgado cessa com o cumprimento ou a extinção da pena, independendo de reabilitação ou de prova de reparação dos danos" (BRASIL, 2010, p. 2093).

A interpretação constitucional dessa norma tão rigorosa é categórica, tendo em vista que não há nenhuma hipótese de o apenado não perder seus direitos políticos, sendo a única forma de reconquistá-los o término do cumprimento da pena.

Moraes (2003, p. 258) coloca que:

Todos os sentenciados que sofrerem condenação criminal com trânsito em julgado estão com seus direitos políticos suspensos até que ocorra a extinção da punibilidade, como consequiência automática e inafastável da sentença condenatória. A duração dessa suspensão cessa com a ocorrência da extinção da punibilidade, seja pelo cumprimento da pena, seja por qualquer outras das espécies previstas no Código Penal, independentemente de reabilitação ou de prova de reparação de danos. 
Cumpre registrar a possibilidade de se suspender apenas parcialmente os direitos políticos, segundo o entendimento de Joel J. Cândido (1991, p. 92), após o cumprimento da pena, pelo período de 3 anos, nos casos previstos na Lei de Inelegibilidade n ${ }^{\circ}$ 64/90 (BRASIL, 2010, p. 1441), artigo $1^{\circ}$, inciso I, letra $e$ :

\author{
Art. $1^{\circ}$ São inelegíveis: \\ I - para qualquer cargo: \\ [...] \\ e) os que forem condenados criminalmente, com sentença transitada em julgado, pela \\ prática de crimes contra a economia popular, a fé pública, a administração pública, o \\ patrimônio público, o mercado financeiro, pelo tráfico de entorpecentes e por crimes \\ eleitorais, pelo prazo de 3 (três) anos, após o cumprimento da pena.
}

A inelegibilidade legal encontra seu fundamento no artigo $14, \S 9^{\circ}$, da Constituição Federal e deve ser distinguida do prescrito no artigo 15, inciso III, do mesmo Estatuto. Não obstante ambas as previsões constitucionais acarretam privação da capacidade eleitoral, a primeira restringe apenas a capacidade eleitoral passiva: ser votado, enquanto que a segunda, a capacidade eleitoral ativa e passiva: votar e ser votado.

No que diz respeito à não suspensão dos direitos políticos dos condenados criminalmente, a doutrina diverge acerca da ocorrência de suspensão condicional da pena, o sursis. O entendimento majoritário é que, durante o prazo do sursis, persiste a sanção política porque prosseguem os efeitos da condenação, no caso, a suspensão dos direitos políticos. Corrobora a tese a alegação de que o sujeito, pelo fato de já ter sido beneficiado pelo sursis ainda teria uma pena acessória - a suspensão de seus direitos tendo em vista sua condenação transitada em julgado.

O Superior Tribunal Federal, em face do disposto no art. 15, III, da Constituição Federal, decidiu que "a suspensão dos direitos políticos se dá ainda quando, com referência ao condenado por sentença criminal transitada em julgado, esteja em curso o período da suspensão condicional da pena." (Supremo Tribunal Federal. Recurso Extraordinário ${ }^{\circ}$ 179502.6/SP.TP do STF, Relator: Ministro Moreira Alves, julgado em 31.05.1995). 
Nesse âmbito, Pedro Henrique Távora Niess ${ }^{4}$, citado por Kimura (2006, p. 40), no Parecer $n^{\circ} 567 / 1996$, proferido nos autos do processo $n^{\circ} 10.574 / 1996$ - Recurso opinou pela privação dos direitos políticos do condenado ainda que beneficiado pela concessão de sursis.

O Ministro Marco Aurélio, em seu pronunciamento no julgamento do Recurso $\mathrm{n}^{\circ}$ 11.589-SP, ainda no Tribunal Superior Eleitoral relatou:

\begin{abstract}
Não consigo (....) assentar que a simples condenação de alguém transitada em julgado é suficiente, por si só, independentemente do sentido que se dê à parte final do inc. III do art. 15, a conduzir à suspensão abrangente dos direitos políticos, como se esta fosse uma pena acessória. Creio que não podemos conferir ao preceito esse alcance; não podemos dissociar a primeira parte do preceito da final, no que sinaliza quanto à possibilidade de vir à balha obstáculo intransponível, ou seja, um fato que provoque, por si mesmo, como conseqüência, a suspensão dos direitos políticos - e, aqui, refirome ao recolhimento do condenado criminalmente.
\end{abstract}

Refere Cintra Júnior (1996, p. 79) que a maior parte da doutrina tem entendido que o dispositivo do art. 15, inciso III, da Constituição tem conteúdo sancionador.

Não obstante toda a importância e o peso do pensamento de tais jurisconsultos, ainda é Cintra Júnior (1996, p. 93-94) que indaga criticamente:

Teria, porém, o legislador constitucional pretendido impor a todos os condenados, indistintamente, com aquele conteúdo ético de reprovação, a limitação da cidadania? Teria a Constituição da República querido englobar na expressão de seu art. 15, inc. III, todos os efeitos da condenação, seja os primários seja os secundários, para prever a suspensão dos direitos políticos enquanto não declarada extinta a pena ou, ainda mais gravemente, enquanto não reabilitado o agente?

O próprio autor (CINTRA JÚNIOR, 1996, p. 94) responde, ao fundamentar a tese da corrente minoritária:

\begin{abstract}
Não parece seja assim. Sendo o direito de votar e ser votado uma das mais caras expressões da cidadania, não se pode entender que o cidadão o tenha suspenso, sempre que condenado criminalmente - ainda que beneficiado com a suspensão condicional da pena ou punido com multa -, experimentando, por força do artigo 15, III, da Constituição da República, outra pena. Isto significaria impor a todos, igualmente, uma sanção, que pode, dependendo do caso, ter efeitos mais severos que a cominada na legislação penal, que é a própria do delito.
\end{abstract}

\footnotetext{
${ }^{4}$ Pareceres da Procuradoria Regional e Eleitoral de São Paulo, Cadernos de Direito Constitucional e Eleitoral $\mathrm{n}$. 21.735 - Nova Palmeira/PB, j. 14.09.2004, TSE, Relator: Ministro Gilmar Ferreira Mendes, publicada em sessão, no dia do julgamento. Em sentido contrário: “A suspensão dos direitos políticos do condenado somente se concebe quando o cumprimento da pena privativa de liberdade em estabelecimento penal torne inviável o exercício de tais direitos, ou quando houver limitações que impliquem horários de recolhimento ao cárcere, não se aplicando às hipóteses de sursis e livramento condicional" (MINAS GERAIS. Tribunal de Alçada. Apelação n. 247.926-3, $1^{\text {a }}$ Câmara. Relator: Juiz Rosauro Júnior, RT 754/713).
} 
No site do Instituto de Acesso à Justiça, tem-se a posição de João Abílio de Carvalho Rosa, ${ }^{5}$ em seu artigo Direito de Voto do Preso:

O Constituinte Brasileiro de 1988 andou mal ao dar a redação que deu ao Art. 15, inciso III, sem explicitar que, apenas e tão-somente, em razão de sentença condenatória transitada em julgado, a pessoa poderia, excepcionalmente, ser destituída ou suspensa dos seus direitos políticos, de forma justificada, por lei devidamente regulamentada, e depois do devido processo legal. Essa seria a hipótese, ao nosso ver, que se coadunaria com a natureza cidadã de uma Carta Democrática.

No que tange a suspensão dos direitos políticos no caso de improbidade administrativa (art. 15, V), o artigo 37, § $4^{\circ}$ da Carta Magna (BRASIL, 2010. p. 34) dispõe que "os atos de improbidade administrativa importarão a suspensão dos direitos políticos, a perda da função pública, a indisponibilidade dos bens e o ressarcimento ao Erário, na forma e gradação previstas em Lei, sem prejuízo da ação penal cabível."

Desse modo,

as sanções decorrentes de ato de improbidade administrativa, aplicadas por meio da ação civil, não tem natureza penal, e a suspensão dos direitos políticos depende de aplicação expressa e motivada por parte do juízo competente, estando condicionada sua efetividade ao trânsito em julgado da sentença condenatória, consoante previsão legal expressa no art. 20 da Lei $n^{\circ} 8.429 / 1992^{6} .^{7}$

Nota-se, com todas as considerações já expostas, divergências doutrinárias e posições polêmicas acerca da importância do exercício dos direitos políticos em uma Nação que se apresenta como democrática. Destaca-se, ainda, que toda a discussão em torno da fixação do termo inicial e final da suspensão dos direitos políticos torna óbvia a constatação do não impedimento legal do exercício desses direitos pelos denominados presos provisórios. Assim, diante das divergências doutrinárias e limitações legais, os direitos políticos dos presos provisórios permanecem inatacáveis.

\section{O direito ao voto do preso provisório no Brasil}

\footnotetext{
${ }^{5}$ Disponível em: <http://www.iaj.org.br>. Acesso em 12 maio 2017

${ }^{6}$ Art. 20 da Lei $\mathrm{n}^{\circ}$ 8.429/1992 - A perda da função pública e a suspensão dos direitos políticos só se efetivam com o trânsito em julgado da sentença condenatória. BRASIL. Vade Mecum RT. 5 ed. re. ampl. e atual. São Paulo: Editora Revista dos Tribunais, 2010. p. 1534.

${ }^{7}$ BRASIL. Tribunal Superior Eleitoral. Recurso Ordinário $n^{o} 811$ - Afrânio/PE, Relator: Ministro Carlos Eduardo Caputo Bastos, julgado em 25.11.2004, DJ de 2.9.2005, p. 152.
} 
Por preso provisório tem-se a pessoa presa por força de prisão temporária, flagrante ou preventiva, com sentença que ainda não tenha transitado em julgado.

Se faz importante esclarecer que devido ao princípio constitucional da presunção de inocência, disposto no artigo $5^{\circ}$, LVII, agregada ao disposto no artigo 15, inciso III (BRASIL, 2010, p. 18), que prevê a suspensão dos direitos políticos no caso de condenação criminal transitada em julgado, enquanto durarem seus efeitos, tem-se que as pessoas presas provisoriamente estão no pleno gozo dos seus direitos políticos, podendo e devendo exercer sua capacidade eleitoral ativa e passiva - votar e ser votado.

Ainda que o preso provisório esteja em pleno gozo de seus direitos políticos, ele encontra barreiras para exercê-los. Isso porque, a Justiça Eleitoral Brasileira omite-se em adotar medidas necessárias para viabilizar esse direito.

Já a doutrina, muito tem silenciado quanto a esse aspecto, talvez em função da liquidez e certeza do direito, que o torna indiscutível e, portanto, passível de responsabilização do Estado que não tem garantido o exercício do direito de voto aos presos provisórios.

A própria Justiça Eleitoral deixa de instalar urnas eleitorais nos estabelecimentos prisionais, bem como deixa de adotar qualquer outra medida a fim de possibilitar o voto dos presos provisórios, cassando, na prática, o direito fundamental ao sufrágio.

A Resolução n. 23.399/2014, que orientou as eleições majoritárias do ano de 2014, deixa claro a "falta de obrigatoriedade" no cumprimento desse direito. No artigo 19, explícito está que

Art. 19. Os Juízes Eleitorais, sob a coordenação dos Tribunais Regionais Eleitorais, poderão criar seções eleitorais em estabelecimentos penais e em unidades de internação tratadas pelo Estatuto da Criança e do Adolescente, a fim de que os presos provisórios e os internados por ato infracional tenham assegurado o direito de voto. $\S 2^{\circ}$ Só poderão votar nas seções eleitorais mencionadas no caput aqueles que nela se alistarem ou optarem por transferir o título eleitoral para essas seções.

Gize-se que o artigo 25 da mesma resolução também indica que as seções eleitorais somente poderão ser instaladas nos estabelecimentos prisionais com no mínimo cinquenta eleitores aptos a votar.

Desnecessário se torna frisar que tal condição cria embaraços para o voto do preso provisório. Isso porque, fica ao completo arbítrio das autoridades públicas a definição sobre a possibilidade do exercício do direito fundamental de cada cidadão preso. Se a casa prisional não contar com o número mínimo de eleitores estipulado pelo Tribunal Superior Eleitoral, o 
direito ao voto de todos os outros presos provisórios que desejam exercer a sua cidadania, fica prejudicado e a mercê da vontade do Egrégio Tribunal que acaba por escolher quem pode exercer o seu direito constitucionalmente previsto.

Se tais regras fossem seguidas, o Poder Público poderia escolher quem iria participar das eleições. Se não quisesse que determinado grupo participasse, bastaria providenciar a transferência para um estabelecimento que tivesse menos de cinquenta eleitores. Clarividente está que não se pode condicionar de modo absoluto a fruição dos direitos fundamentais de uma minoria estigmatizada às conveniências administrativas da Justiça Eleitoral.

A denegação do direito de voto ao preso provisório compromete totalmente o princípio democrático, que pressupõe a plena inclusão política do povo, ferindo o direito subjetivo, líquido e certo dos presos provisórios de votarem. Este grave quadro de ofensa aos direitos políticos pode ser debitado ao egrégio Tribunal Superior Eleitoral, haja vista que em seus atos normativos não determinada à Justiça Eleitoral que adote todas as providências necessárias à viabilização do voto do preso provisório, mas apenas reconhece uma hipotética faculdade no âmbito dos Tribunais Regionais Eleitorais.

Tal faculdade, acaba fazendo com que a maioria dos Tribunais Regionais não se interesse pelo assunto, tendo em vista que não precisam cumprir ordem imediata a respeito do voto do preso provisório.

\subsection{O voto dos presos provisórios em outros países}

Como instrumento útil se apresenta o estudo comparado com outros países acerca do tratamento oferecido às pessoas presas. Em se tratando de assunto polêmico, cuja discussão tem sido rarefeita na doutrina, espera-se encontrar apoio à defesa do direito de voto do preso provisório também nas normas estrangeiras, em razão da diversidade de cultura, visto ser esta o fator determinante do modo de agir de um povo com seus indivíduos.

A União Européia prolatou decisão favorável ao exercício do voto do preso ao apreciar a lei que proíbe o voto do preso na Inglaterra, na expectativa de que os países-membros acatem a decisão. A Suprema Corte Canadense também optou pela decisão favorável de tal direito político em seu país, sendo que os canadenses que alcançaram os 18 anos até o dia da eleição e que estão atualmente em uma instituição correcional ou numa penitenciária federal também podem votar. Na Europa, cerca de 20 Estados já asseguram e adotam o direito político às 
pessoas presas. Em Portugal, os presos podem votar antecipadamente desde que não estejam privados de direitos políticos. $\mathrm{O}$ fato da votação ser antecipada faz com que se evite problemas de informática, falta de estrutura, etc, salienta Rodrigo Tönniges Puggina (2006, p. 286). A informação prestada pela Diretora de Serviços da Divisão de Apoio Jurídico do Consulado de Portugal, Maria da Graça Archer, dá conta que:

\begin{abstract}
Os cidadãos presos podem votar antecipadamente, desde que não estejam privados de direitos políticos. Para o efeito, devem requerer ao presidente da câmara do município em que se encontrem recenseados, até o $20^{\circ}$ dia anterior ao da eleição, com a documentação necessária ao exercício do direito de voto, enviando fotocópias autenticadas do seu bilhete de identidade e do seu cartão de eleitor e juntando documento comprovativo do impedimento invocado, emitido pelo director do estabelecimento prisional (PUGGINA, 2006, p. 289).
\end{abstract}

$\mathrm{Na}$ Espanha, não existe nenhuma restrição constitucional. A Constituição Espanhola ressalta que o condenado a pena de prisão que a estiver cumprindo gozará de todos os direitos fundamentais, em exceção somente aqueles que estiverem expressamente limitados pelo conteúdo condenatório e que todos os cidadãos tem o direito de participar nos assuntos públicos diretamente ou por meio de representantes eleitos por sufrágio universal (PUGGINA, 2006, p. 287).

Em países como Bulgária e Suíça, os presos também gozam de seu direito político. Como vimos, na Europa não é problema os presos votarem, uma vez que o sufrágio universal é adotado fielmente por todos.

Para deixar explícita toda essa facilidade encontrada no continente europeu, tomamos como exemplo a Itália, que não só busca o voto das pessoas presas como proporciona a todos cidadãos italianos que estão no exterior o exercício do voto.

Alguns países da América do Sul e Central também não tem restrição quanto ao sufrágio em relação ao preso, ou, ainda, necessitam de legislação complementar. Encontram-se neste rol, a Bolívia, Porto Rico e Costa Rica, considerado um país com uma das democracias mais assentes das Américas. Este último, devido a aprovação do "Tribunal Supremo de Elecciones" da Costa Rica de uma reforma acerca do direito político do preso, os presos são tirados individualmente de suas celas e levados sob custódia até outro compartimento das prisões, onde se encontram membros de uma junta eleitoral e fiscais dos partidos, permitindo o voto secreto como o de qualquer outro cidadão costarriquense (PUGGINA, 2006, p. 300). 
O jornal nicaraguense "La Prensa", foi até a prisão na Costa Rica e entrevistou os presos que fizeram uso de seu direito político, os quais alegaram que somente tiveram acesso as informações político-partidárias através do rádio e da televisão e que somente alguns candidatos minoritários foram visitá-los na cadeia. Importante salientar o relato de alguns presos, com a intensão de mostrar o que eles pensam e o que pretendem votando. O preso David Zárate, de 29 anos, declarou: "Eu gostaria que os governantes tomassem consciência de que as pessoas que estão aqui tem família e queremos oportunidades para sermos re-inseridos na sociedade." Outro preso, Arnoldo Mora, de 20 anos, disse o seguinte: "Eu queria pedir ao novo Presidente que trabalhe para que haja menos delinquência e drogas. ” Arnoldo Mora, oriundo de um dos bairros com maiores taxas de violência da capital da Costa Rica, confessa que tem dez meses que está preso, por roubo com agravante, mas que se considera uma vítima, pois a prisão "é um lugar muito duro para viver” (CHACÓN, 2002, p. 34).

Ao analisar diversos aspectos, tem-se que o preso acaba muitas vezes sendo esquecido pelos governantes, o que se pode notar principalmente pelos estados dos presídios. O que parece é que pelo fato do indivíduo estar recluso, ele acaba por não participar mais da sociedade, perdendo totalmente sua cidadania.

Ilustrando um pouco mais um sistema realmente democrático, Mariano Barrantes, o Diretor do Centro Penal de Sebastián, declara que nestas últimas eleições não somente os presos que lá se encontravam no dia das eleições puderam votar, mas, também, aqueles que foram liberados, mas não mudaram seu domicílio eleitoral a tempo. Em Porto Rico, observa-se que os presos votam para aqueles que eles sentem que beneficiarão suas famílias e não naqueles que eles pensam ser melhores para eles. Outros países como o Peru, por exemplo, ainda lutam pelo direito de voto das pessoas processadas ainda sem condenação (PUGGINA, 2006, p. 282).

Puggina (2006, p. 285) assinala ainda um exemplo irônico na Argentina, onde também existe um movimento em relação ao voto do preso, com decisão favorável da "Corte Suprema de Justicia”, que mostra como um direito fundamental não pertence à vontade política deste ou daquele governo. O Jornal "Clarín”, de 12 de julho de 2001, com o título de "O ex-presidente prova uma dose de sua própria medicina", aponta que, quando no ano de 1998 a Justiça estudava a possibilidade de autorizar o voto dos presos sem condenação, o governo de Menem se opôs enfaticamente e considerou perfeitamente constitucional a norma impeditiva para o voto das pessoas presas provisoriamente. Na época, era inimaginável que três anos depois Carlos Menem estivesse preso preventivamente pela venda ilegal de armas, privado de seus direitos políticos. 
Assim, o ex-presidente, durante sua prisão domiciliar de quase seis meses, tentou desqualificar e relativizar aquela norma e se amparar na Convenção Americana de Direitos Humanos, para sustentar sua candidatura a senador suplente.

Servem de exemplo também países como Palestina, Iraque e Irã. A Palestina, por exemplo, teve recurso negado, sob o argumento de que não teria condições para preparar o escrutínio dos presos em pouco tempo. No Iraque, os presos puderam votar, acompanhados pelo exército americano, o que causou embaraço ao governo norte-americano pelo fato dos Estados Unidos não permitirem que os presos de seu país votem (PUGGINA, 2006, p. 289).

Um país que busca 'exportar democracia' para o Iraque como os Estados Unidos tem muito a 'importar democracia' de lá. Falar em voto dos presos nos Estados Unidos é falar muito mais em política do que qualquer outra coisa. Puggina salienta que os republicanos são contrários ao voto dos presos, enquanto os democratas são favoráveis e que existe uma grande luta de movimentos sociais por este direito, que consideram a negação uma discriminação, e dizem que a briga se deve pelo fato da grande maioria dos presos serem pessoas pobres, negras e latinas, as quais apresentam maior probabilidade de votar em democratas (PUGGINA, 2006, p. 289).

Diante da análise da votação dos presos provisórios em outros países, percebe-se que todas as formas de restrição ao direito de sufrágio acabam por expor atitudes antidemocráticas que propiciam a manutenção da exclusão do indivíduo da sociedade.

\section{Considerações finais}

No Brasil o voto não é só um direito, mas também um dever que, se não cumprido, acarreta inúmeras complicações, inclusive dá ensejo ao pagamento de multa. Assim é para todos; porém, para os presos provisórios, esse direito é condicionado a uma série de obstáculos, que impedem a sua materialização, fazendo do preso um meio ou um não cidadão, pois lhe é usurpado o exercício de sua cidadania.

O objetivo precípuo deste estudo foi demonstrar a flagrante inconstitucionalidade pela inobservância dos efeitos advindos do artigo 15, inciso III da Constituição Federal, que coloca como suspensos os direitos políticos somente daqueles que tenham condenação criminal transitada em julgado. Ocorre que os presos provisórios gozam da sua capacidade eleitoral 
plena, podendo exercê-la tanto ativa quanto passivamente, ou seja, podem eleger representantes políticos e serem eleitos.

A indagação sobre os motivos pelos quais os presos provisórios não tem exercido o direito de voto surgiu após a constatação de que os seus direitos políticos não estão suspensos. O que acontece é uma grande afronta à Carta Magna pela inobservância dos efeitos do artigo 15, inciso III, que se refere ao fato de que os presos provisórios não tem os seus direitos políticos suspensos e estão obrigados, assim como os demais cidadãos, a exercer sua cidadania através do voto. Tal direito vem sendo sistematicamente denegado em razão da omissão da própria Justiça Eleitoral em adotar as medidas necessárias à sua viabilização.

Esse gravíssimo quadro de ofensa aos direitos políticos essenciais dos presos provisórios pode, em parte, ser debitado ao Egrégio Tribunal Superior Eleitoral, eis que nunca determinou à Justiça Eleitoral que adotasse todas as providências necessárias à viabilização do voto do preso provisório, apenas reconhecia uma hipotética faculdade de que isso fosse feito no âmbito dos Tribunais Regionais Eleitorais. Tal faculdade fazia com que a maioria dos Tribunais Regionais não se interessassem pelo assunto, tendo em vista que não precisavam cumprir ordem imediata a respeito do voto do preso provisório.

Ocorre que não se pode comprometer a integridade do princípio democrático, que pressupõe a plena inclusão política do povo, ferindo o direito subjetivo, líquido e certo dos presos votarem.

O preso, que sofre a exclusão social na sua vivência diária, sabe o que é não ter voz ativa para lutar por seus direitos. Não é porque ele está preso que perdeu todos os seus direitos. Aumentar a desigualdade, enfraquecendo a democracia, faz com o que todos os presos que já se encontram em desigualdade frente as pessoas livres, percam a vontade de lutar por aquilo que ainda resta. $\mathrm{O}$ fato de excluir ainda mais os presos torna-se uma prática inaceitável e totalmente antidemocrática.

No momento em que o indivíduo fica recluso, já lhe é dada a punição pelo crime cometido: a privação de liberdade. Não podemos puni-lo novamente, com a retirada de seus direitos políticos, pois é vedado em nosso ordenamento punir duas vezes o mesmo indivíduo pelo mesmo crime. Nesse compasso, deve-se balizar tão somente a aplicação da pena privativa de liberdade como repúdio pela conduta delituosa, sem atingir quaisquer outros direitos do preso provisório, principalmente o direito de votar. 
O não reconhecimento do voto do preso provisório quebra as bases da democracia, ferindo o princípio da igualdade, da não-discriminação e da soberania popular. Isso é repugnante e marginalizador, estando bem longe a proposta de Constituição Cidadã, como intitulou-se a nossa Magna Carta. Usurpar esse direito dos presos provisórios vem reforçar as situações de domínio, comparáveis ao antigo sistema colonialista, em que a classe dominante do poder, rica, afastava o homem comum e humilde de sua cidadania, que lhe era arrancada.

No entanto, do modo em que está sendo interpretado, pela grande maioria da doutrina e dos aplicadores do Direito, o dispositivo constitucional em questão está acarretando ao apenado a privação de sua liberdade e, ainda, a privação do exercício de sua cidadania, o que é inadmissível ocorrer.

Por todo o exposto, é fundamental que se permita que o preso provisório vote, afinal ninguém melhor do que ele para descrever o sentimento de ser excluído e de sofrer com o voto dos outros, porque a deliberação estatal atinge a todos, não só aos que possuem direitos políticos ativos.

\section{Referências}

BONAVIDES, Paulo. Curso de Direito Constitucional. 12. ed. São Paulo: Malheiros, 2002.

BRASIL. Lei $\mathrm{n}^{\circ}$ 8.239, de 4 de Outubro de 1991. Disponível em: <https://www.planalto.gov.br /ccivil_03/leis/18239.htm> Acesso em 15 abr. 2017.

. Tribunal Superior Eleitoral. Recurso Ordinário n⿳ 1069/RJ. Relator: Marcelo Henriques Ribeiro de Oliveira, julgado em 20.09.2006.

. Supremo Tribunal Federal. Recurso Extraordinário no 179502.6/SP. Relator: Ministro Moreira Alves, julgado em 31.05.1995.

. Tribunal Superior Eleitoral. Recurso Ordinário no 811 - Afrânio/PE, Relator: Ministro Carlos Eduardo Caputo Bastos, julgado em 25.11.2004.

Tribunais, 2010 .

Vade Mecum RT. 5 ed. re. ampl. e atual. São Paulo: Editora Revista dos

CÂNDIDO, Joel J. Inelegibilidades no Direito Brasileiro. 2 ed., ver., ampl. e atual. BauruSP: EDIPRO, 2003.

CARRERAS, Francesc de \& VALLES, Josep M. Las Elecciones. Barcelona: Blume, 1977. Tradução livre. 
CINTRA JUNIOR, Dyrceu Aguiar Dias. A suspensão dos direitos políticos em face dos princípios da individualização da pena e da proporcionalidade. In: Revista Brasileira de Ciências Criminais. São Paulo: Revista dos Tribunais. Ano 4. n. 15, jul/set. 1996.

COÊLHO, Marcus Vinícius Furtado. Direito eleitoral e processo eleitoral. Rio de Janeiro: Renovar, 2008.

DECLARAÇÃO Universal dos Direitos Humanos. Disponível em: <http://portal.mj.gov.br/sedh/ ct/legis_intern/ddh_bib_inter_universal.htm> Acesso em 22 abr. 2017.

DÓRIA, Sampaio. Comentários à Constituição de 1946. São Paulo: Max Limonad Editor, 1960. v. 2.

HAURIOU, Maurice. Princípios de derecho publico y constitucional. Tradução de Carlos Ruiz del Castillo. Granada: Comares, 2003.

KIMURA, Alexandre Issa. Manual de direito eleitoral. São Paulo: Editora Juarez de Oliveira, 2006.

MORAES, Alexandre de. Direito Constitucional. 13.ed. São Paulo: Atlas, 2003.

NIESS, Pedro Henrique Távora. 1950. Direitos Políticos - Elegibilidade, inelegibilidade e ações eleitorais. $2^{a}$ ed. revista e atualizada. Bauru, SP: Edipro, 2000.

PAIVA, Maria Arair Pinto. Direito Político do Sufrágio no Brasil (1822 - 1982). Brasília: Thesaurus, 1985.

PUGGINA, Rodrigo. O Direito de Voto do Preso. Revista da AJURIS, dez. 2006, Ano XXXIII, v. 33, n. 104. Porto Alegre/RS.

REALE, Miguel. Teoria do direito e do Estado. 5. ed. São Paulo: Saraiva, 2000.

SILVA, De Plácido e. Vocabulário jurídico. 18.ed. Rio de Janeiro: Forense, 2001.

SILVA, José Afonso da. Curso de Direito Constitucional Positivo. 21. ed. São Paulo: Malheiros, 2002.

ZILIO, Rodrigo López. Direito Eleitoral: noções preliminares, elegibilidade e inelegibilidade, processo eleitoral (da convenção à prestação de contas), ações eleitorais. Verbo Jurídico, 2008, Porto Alegre. 